\title{
Desulforegula conservatrix gen. nov., sp. nov., a long-chain fatty acid-oxidizing, sulfate- reducing bacterium isolated from sediments of a freshwater lake
}

\author{
1 University of Canberra and \\ CRC for Freshwater \\ Ecology/Murray-Darling \\ Freshwater Research \\ Centre, PO Box 921 Albury, \\ NSW 2640, Australia \\ 2 School of Biomedical and \\ Molecular Biology, Griffith \\ University, Nathan, \\ Queensland 4111, \\ Australia
}

\author{
Gavin N. Rees ${ }^{1}$ and Bharat K. C. Patel ${ }^{2}$ \\ Author for correspondence: Gavin N. Rees. Tel: +6126058 2356. Fax: +61260431626. \\ e-mail: rees@mdfrc.canberra.edu.au
}

\begin{abstract}
A novel sulfate-reducing bacterium, strain $\mathrm{Mb}^{\mathrm{P}} \mathrm{Pa}^{\top}$, was isolated from the sediments of a freshwater floodplain lake. Cells of strain $\mathrm{Mb}^{1 \mathrm{~Pa}^{\top}}$ were rodshaped, 1-1.3 $\mu \mathrm{m}$ wide and 2.6-3 $\mu \mathrm{m}$ long, motile and Gram-negative. The bacterium grew on straight-chain carboxylic acids with 4-17 carbon atoms. Electron donors with an even number of carbon atoms were oxidized to acetate and electron donors with an odd number of carbon atoms were oxidized to acetate and propionate. No other compounds were found to be used as electron donors. No growth occurred in the absence of sulfate. The optimum temperature for growth was between 25 and $30^{\circ} \mathrm{C}$ and the maximum temperature for growth was $32{ }^{\circ} \mathrm{C}$. Strain $\mathrm{Mb} 1 \mathrm{~Pa}^{\top}$ grew very slowly in medium with $5 \mathrm{~g} \mathrm{NaCl} \mathrm{I}^{-1}$ with optimum growth occurring with up to $1.0 \mathrm{~g} \mathrm{NaCl} \mathrm{I}^{-1}$. Analysis of the 165 rRNA gene showed that strain $\mathrm{Mb1Pa}^{\top}$ belonged to the $\delta$ subclass of the Proteobacteria, was a member of the family Desulfobacteraceae, but lacked similarity with any currently described representatives. The combined phylogenetic analysis and physiological data indicate that strain $\mathrm{Mb}^{1 \mathrm{~Pa}^{\top}}$ represents a new genus and the name Desulforegula conservatrix is proposed. The type strain is $\mathrm{Mb}^{1 \mathrm{~Pa}^{\top}}$ (= DSM $13527^{\top}=$ ATCC BAA-134 $^{\mathrm{T}}$ ).
\end{abstract}

Keywords: Desulforegula conservatrix, sulfate-reducing bacteria, long-chain fatty acids, sediment 
paper, we describe the isolation and characterization of strain $\mathrm{Mb} 1 \mathrm{~Pa}^{\mathrm{T}}$.

\section{METHODS}

Isolation and culture conditions. Strain $\mathrm{Mb} 1 \mathrm{~Pa}^{\mathrm{T}}$ was isolated by enrichment from the sediment of a wetland lake that is on the floodplain of the River Murray, Albury, Australia. Primary enrichment cultures contained approximately $1 \mathrm{~g}$ sediment in $10 \mathrm{ml}$ medium that had been supplemented with $1 \mathrm{mM}$ sodium palmitate. Palmitate continued to be supplied as the electron donor throughout the enrichment stages but was replaced with butyrate for final purification by agar shake dilution tubes. Dilute freshwater medium (Janssen et al., 1997) preparation and anaerobic culture techniques were used throughout this study, with all media prepared as described previously (Rees et al., 1995). Substrates and electron acceptors were added as required from sterile stock solutions. All incubations were carried out at $25^{\circ} \mathrm{C}$. When necessary, Desulfovibrio desulfuricans DSM 642 was used as a control for growth experiments.

Cellular and metabolic characterization. Desulfoviridin was determined by the fluorescence test (Postgate, 1959) but with the fluorescence detection carried out with a fluorescence spectrophotometer. The pellet from $30 \mathrm{ml}$ culture was washed and resuspended in $2 \mathrm{ml}$ phosphate buffer $(50 \mathrm{mM}$, $\mathrm{pH} 7$ ). Following addition of 2 drops $2 \mathrm{M} \mathrm{NaOH}$, the suspension underwent UV excitation in a Hitachi F4500 spectrofluorimeter and an emission spectrum was obtained from 500 to $800 \mathrm{~nm}$. The presence of desulfoviridin was demonstrated by a single large peak with an emission maximum at $712 \mathrm{~nm}$. The lipid nature of cell inclusions was demonstrated by staining with Nile blue (Ostle \& Holt, 1982). Organic acids were determined by GC as described previously (Rees et al., 1997). Dry mass measurements were carried out as described previously (Rees et al., 1994).

DNA base composition and phylogenetic analysis. For phylogenetic studies, genomic DNA was purified from strain $\mathrm{Mb} 1 \mathrm{~Pa}^{\mathrm{T}}$ by the methods described by Ausubel et al. (1997). The universal primers Fd1 and Rd1 were used to obtain a PCR product of approximately $1.5 \mathrm{~kb}$ corresponding to base positions 1-1542 based on Escherichia coli numbering of the 16S rRNA gene (Winker \& Woese, 1991) using procedures described previously (Redburn \& Patel, 1993; Andrews \& Patel, 1996). PCR products were sequenced using the ABI PRISM Dye Terminator Cycle Sequencing Kit containing AmpliTaq FS DNA polymerase and using an ABI 373A sequencer. A $10 \mu \mathrm{l}$ reaction contained $35 \mathrm{ng}$ PCR product, $4 \mu \mathrm{l}$ cycle sequencing reaction mix, $3 \cdot 2 \mathrm{pmol}$ primer (Andrews \& Patel, 1996) and 2.5 $\mu \mathrm{g}$ BSA. Thermal cycling was carried out using a Rapid Cycler (Idaho Technology) at a temperature transition slope of 2 , an initial denaturation of $94{ }^{\circ} \mathrm{C}$ for $15 \mathrm{~s}$, then 25 cycles of denaturation at $94{ }^{\circ} \mathrm{C}$ for $0 \mathrm{~s}$, annealing at $50^{\circ} \mathrm{C}$ for $10 \mathrm{~s}$, and extension at $60^{\circ} \mathrm{C}$ for $3 \mathrm{~min}$.

The new sequence data that were generated were aligned, and an almost full-length consensus 16S rRNA gene sequence was assembled and manually checked for accuracy using the alignment editor ae2 (Maidak et al., 2000). These sequences were compared with others in the GenBank database (Benson et al., 2000) using BLAST (Altschul et al., 1997), to determine if any newly released closely related sequences existed in the database. For analysis, the sequences of Desulfofrigus oceanense, Desulfofrigus fragile, Desulfofaba gelida, Desulfobacterium phenolicum, strain R-
Capr A1, Desulfobacterium indolicum, Desulfonema limicola, Desulfonema magnum, Desulfonema ishimotonii, Desulfobacterium cetonicum, Desulfobacterium anilini, 'Desulfobotulus sapovorans', Desulfococcus multivorans and Desulfosarcina variabilis were extracted from GenBank and manually aligned with the prealigned sequences obtained from the Ribosomal Database Project (Maidak et al., 2000). Pairwise evolutionary distances based on 733 unambiguous nucleotides were computed using DNADIST (Jukes \& Cantor, 1969) and neighbour-joining programs that form part of the PHYLIP suite of programs (Felsenstein, 1993).

For DNA base compositions studies, a total of four different methods to isolate DNA were carried out independently in three different laboratories. The methods used were those of Marmur (1961) and Pitcher et al. (1989), and also small-scale preparation involving hexadecyl trimethylammonium bromide precipitation (Woo et al., 1997) and extraction with guanidine. $\mathrm{HCl}$ (Janssen \& O'Farrell, 1999). In addition to following procedures outlined in the original methods, additional modifications were made to try and obtain suitable DNA preparations. Significant modifications included introducing chloroform during early stages of the protocols to eliminate lipid storage globules interfering with DNA isolation, and using protease treatments early in the procedure to destroy nuclease activity.

\section{RESULTS AND DISCUSSION}

\section{Morphological and physiological characteristics}

Primary enrichment cultures with palmitate and lake sediment appeared to be totally dominated by rodshaped cells. A pure culture was subsequently obtained and designated strain $\mathrm{Mb} 1 \mathrm{~Pa}^{\mathrm{T}}$. Cells of strain $\mathrm{Mb} 1 \mathrm{~Pa}^{\mathrm{T}}$ were rod-shaped, $1-1 \cdot 3 \mu \mathrm{m}$ wide and $2 \cdot 6-3 \mu \mathrm{m}$ long (Fig. 1). Motile cells were observed in early growth phases but at less frequency in older cultures. Cells

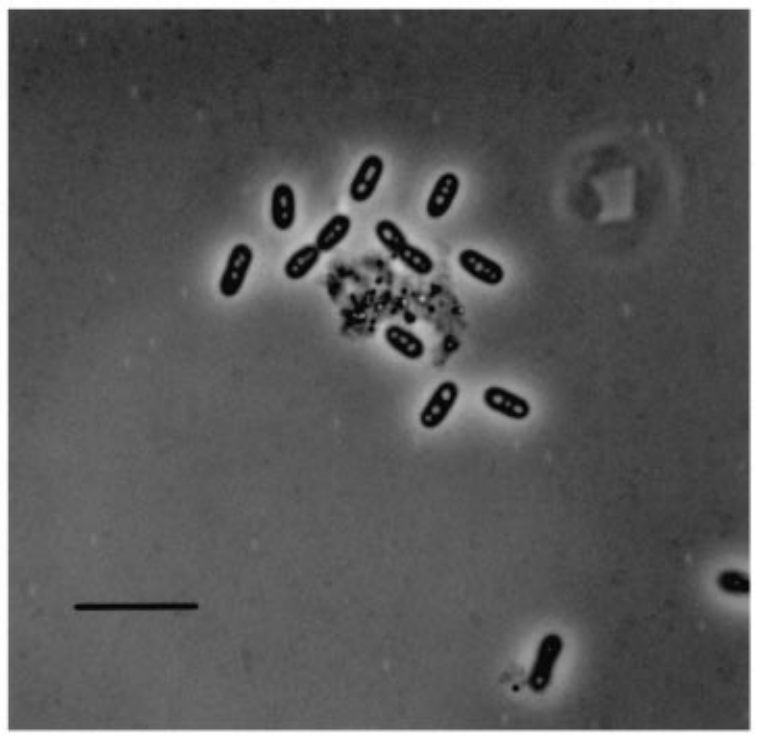

Fig. 1. Phase-contrast photomicrograph of Desulforegula conservatrix strain $\mathrm{Mb}^{1 \mathrm{~Pa}^{\top}}$. Bar, $10 \mu \mathrm{m}$. 


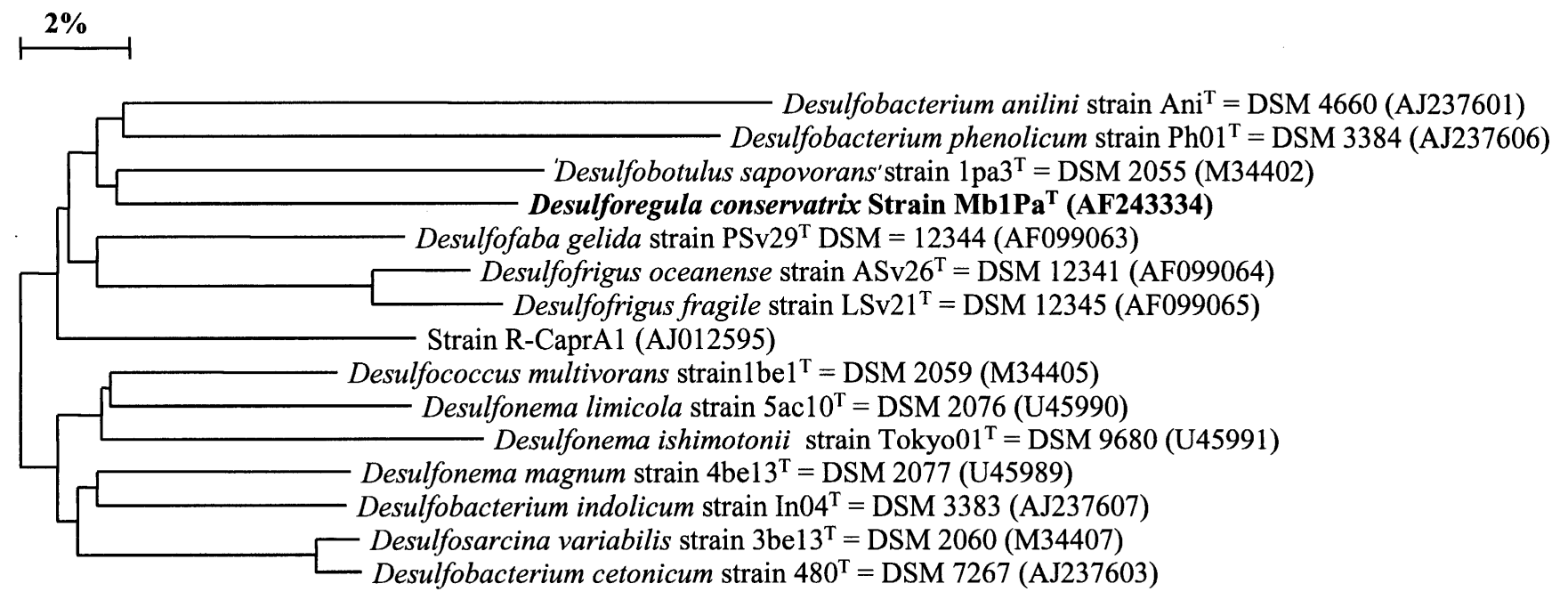

Fig. 2. Phylogenetic tree showing the position of Desulforegula conservatrix strain $\mathrm{Mb}^{1} \mathrm{~Pa}^{\top}$ compared to some of the closest members of the $\delta$-subclass of the Proteobacteria. Scale bar equals substitutions per 100 nucleotides.

stained Gram-negative and spores were not observed in any cultures. Cellular inclusions could be stained with Nile blue, indicating that the inclusion bodies were poly-3-hydroxybutyrate.

When growing under optimal conditions with $10 \mathrm{mM}$ butyrate, subcultures $(1 \%, \mathrm{v} / \mathrm{v}$, inoculum) from an early stationary phase culture usually reached a maximum cell yield within 3-4 d. However, when cultures were stored for more than 4 weeks, subsequent subcultures had lag periods that were often greater than 1 week. The lag period could be reduced by including dithionite in the medium to give $100 \mu \mathrm{M}$ final concentration.

Although strain $\mathrm{Mb} 1 \mathrm{~Pa}^{\mathrm{T}}$ was isolated with a dilute salts medium, it grew equally well in standard freshwater medium containing $1 \mathrm{~g} \mathrm{NaCl} 1^{-1}$ (Widdel \& Bak, 1992). Growth occurred in medium with $5 \mathrm{~g} \mathrm{NaCl}^{-1}$ but cultures required incubation for 2 weeks before measurable growth occurred. Strain $\mathrm{Mb} \mathrm{Pa}^{\mathrm{T}}$ grew with an incubation temperature up to $32^{\circ} \mathrm{C}$, with optimum growth occurring at between 25 and $30^{\circ} \mathrm{C}$. A vitamin supplement was required for growth. Yeast extract could not replace the vitamin supplement.

The compounds that were used as electron donors by strain $\mathrm{Mb}_{1 \mathrm{~Pa}^{\mathrm{T}}}$ were $(\mathrm{mM})$ : butyrate (5), valerate (5), hexanoate (5), octanoate (1), decanoate $(0.25)$, dodecanoate $(0 \cdot 25)$, hexadecanoate (1) and heptadecanoate (1). Compounds not used by strain $\mathrm{Mb} 1 \mathrm{~Pa}^{\mathrm{T}}$ were: lactate (10), pyruvate (10), malate (5), succinate (5), fumarate (5), ethanol (10), formate (5), formate (5) plus acetate (1), acetate (10), propionate (5), octadecanoate (1), glucose (5), benzoate (5) and citrate (5). Growth on decanoate occurred only when the concentration in the medium was no greater than $0.25 \mathrm{mM}$; growth was confirmed following additions of very small amounts of decanoate to cultures over time. The presence of $1.0 \mathrm{mM}$ decanoate was sufficient to completely inhibit growth on butyrate.

Stoichiometric measurements demonstrated that the oxidation of $7.99 \mathrm{mmol}$ butyrate $1^{-1}$ yielded $14 \cdot 17 \mathrm{mmol}$ acetate $1^{-1}$ and $47 \mathrm{mg}$ dry mass of cells $1^{-1}$. These data represent a carbon recovery of $94.6 \%$. When strain $\mathrm{Mb} \mathrm{Pa}^{\mathrm{T}}$ oxidized valerate, acetate and propionate were produced in equimolar amounts. The oxidation of heptadecanoic acid resulted in an acetate to propionate ratio of 7 . These stoichiometry studies are consistent with the incomplete oxidation of fatty acids as described by Widdel (1980). Strain $\mathrm{Mb}^{\mathrm{Pa}} \mathrm{Pa}^{\mathrm{T}}$ was unable to ferment pyruvate, fumarate or malate. Sulfite, thiosulfate or nitrate were not used as terminal electron acceptors.

All attempts to isolate DNA for base composition studies failed. Cells were easily lysed; however, all subsequent procedures to isolate sufficient quantities of DNA, whether from original protocols or modification methods, failed. Cells contained desulfoviridin.

\section{Phylogenetic analysis and taxonomic affiliation}

Phylogenetic analysis showed that strain $\mathrm{Mb} \mathrm{Pa}^{\mathrm{T}}$ was a member of the $\delta$-subclass of the Proteobacteria and formed a new branch within the proposed family Desulfobacteraceae. The 16S rRNA gene sequence of $\mathrm{Mb} 1 \mathrm{~Pa}^{\mathrm{T}}$ was not highly similar to any sequence in public databases. Instead, there were four strains with similarity between 89.4 and $89.9 \%$. The most closely related organisms in the molecular database were strain R-Capr A1 (89.9\% similarity), Desulfofaba gelida (89.9\% similarity), Desulfobacterium indolicum (89.6\% similarity) and Desulfonema limicola (89.4\% similarity) (Fig. 2). 
Table 1. Summary of morphological and physiological characteristics of strain $\mathrm{Mb} \mathrm{Pa}^{\top}$ and related SRB

$(+)$, Weak growth; NR, not reported.

\begin{tabular}{|c|c|c|c|c|c|}
\hline & $\begin{array}{c}\text { Desulforegula } \\
\text { conservatrix } \\
\text { strain } \mathrm{Mb}^{\mathrm{P} \mathrm{Pa}^{\mathrm{T}}}\end{array}$ & $\begin{array}{l}\text { Desulfofaba } \\
\text { gelida } \\
\text { strain PSv29* }\end{array}$ & $\begin{array}{c}\text { Desulfobacterium } \\
\text { indolicum } \\
\text { strain In04 } \uparrow\end{array}$ & $\begin{array}{l}\text { Desulfonema } \\
\text { limicola } \\
\text { strain 5ac10 }\end{array}$ & $\begin{array}{c}\text { 'Desulfobotulus } \\
\text { sapovorans' } \\
\text { strain 1pa3§ }\end{array}$ \\
\hline Morphology & Rod shaped & Slightly curved rod & Rod-shaped & Filamentous & Vibrio \\
\hline \multicolumn{6}{|l|}{ Cell size $(\mu \mathrm{m})$ : } \\
\hline Width & $1-1 \cdot 3$ & $3 \cdot 1$ & $0 \cdot 7-1 \cdot 5$ & $2 \cdot 5-3$ & $1 \cdot 5$ \\
\hline Length & $2 \cdot 6-3$ & $3 \cdot 2-6 \cdot 2$ & $2-2 \cdot 5$ & $\begin{array}{c}50-1000 \mu \mathrm{m} \\
(2 \cdot 5-3 \text { one cell })\end{array}$ & $3-3 \cdot 5$ \\
\hline Motility & + & + & + & + & + \\
\hline Oxidation of substrate & Incomplete & Incomplete & Complete & Complete & Incomplete \\
\hline \multicolumn{6}{|l|}{ Electron donors used: } \\
\hline $\mathrm{H}_{2}$ & - & - & - & + & - \\
\hline Formate & - & + & $(+)$ & + & - \\
\hline Acetate & - & - & $(+)$ & $(+)$ & - \\
\hline Fatty acids (C atoms) & $4-17$ & $3-4$ & (3) & $3-14$ & $4-16$ \\
\hline Lactate & - & + & - & + & + \\
\hline Fumarate & - & + & $(+)$ & + & - \\
\hline Ethanol & - & + & $(+)$ & - & - \\
\hline Ferment pyruvate & - & + & $\mathrm{NR}$ & - & + \\
\hline \multicolumn{6}{|l|}{ Electron acceptors used: } \\
\hline Sulfite & - & + & - & + & + \\
\hline Thiosulfate & - & + & + & + & - \\
\hline Sulfur & - & - & - & - & - \\
\hline Desulfoviridin & + & - & - & + & - \\
\hline
\end{tabular}

* Knoblauch et al. (1999).

$\dagger$ Bak \& Widdel (1986).

+ Widdel et al. (1983).

$\S$ Widdel \& Bak (1992).

Strain $\mathrm{Mb} 1 \mathrm{~Pa}^{\mathrm{T}}$ oxidized long-chain fatty acids, a trait which is in common with isolates obtained from a variety of sediment types. For example, 'Desulfobotulus sapovorans' was isolated from mud of a ditch in a dairy pasture (Widdel, 1980). In addition to 'Desulfobotulus sapovorans', Widdel (1980) also described two further strains, 2 pa3 and 3 pa8, that also were able to oxidize straight-chain fatty acids with 4-18 carbon atoms. Also, an uncharacterized ovalshaped organism that was able to oxidize long-chain fatty acids was referred to by Widdel (1988). Strain $\mathrm{Mb} 1 \mathrm{~Pa}^{\mathrm{T}}$ and 'Desulfobotulus sapovorans' carry out incomplete oxidation of a relatively narrow range of long-chain fatty acids. However, significant phenotypic and phylogenetic differences exist between these organisms (Table 1). The organism with closest sequence similarity to strain $\mathrm{Mb} 1 \mathrm{~Pa}^{\mathrm{T}}$ is Desulfofaba gelida ( $89.9 \%$ similarity); however, this organism has physiological characteristics that are significantly different from those of $\mathrm{Mb} \mathrm{Pa}^{\mathrm{T}}$ (Knoblauch et al., 1999) (Table 1). Desulfofaba gelida incompletely oxidizes its substrates; however, it is a psychrophilic sulfate reducer that can oxidize alcohols and dicarboxylic acids and it cannot use straight-chain carboxylic acids with more than 4 carbon atoms. Strain R-Capr A1 has sequence similarity with strain $\mathrm{Mb} \mathrm{Pa}^{\mathrm{T}}$ of $89.9 \%$ (Wind et al., 1999). This organism has a limited substrate range and incompletely oxidizes hexanoate and alcohols, but as yet has not been tested for growth on long-chain fatty acids. Desulfobacterium indolicum ( $89.6 \%$ similarity) differs from $\mathrm{Mb} \mathrm{Pa}^{\mathrm{T}}$ by its ability to completely oxidize acetate and propionate and also being unable to use long-chain fatty acids (Bak \& Widdel, 1986). Strains of Desulfobacterium indolicum have been isolated from brackish and marine environments whereas strain $\mathrm{Mb}_{1 \mathrm{~Pa}^{\mathrm{T}}}$ was obtained from freshwater sediment. Desulfonema spp. are conspicuous filamentous SRB that exhibit gliding motility (Widdel et al., 1983). Sequence comparison showed a relatively distant relationship to Desulfonema limicola. Similarly, significant morphological and physiological differences were observed between these two organisms (Table 1). Given the distance from the nearest relatives, combined with the physiological differences with any related organisms, we propose that strain $\mathrm{Mb} 1 \mathrm{~Pa}^{\mathrm{T}}$ represents a new species of a new genus. We propose the name Desulforegula conservatrix gen. nov., sp. nov. 


\section{Description of Desulforegula gen. nov.}

Desulforegula (De.sul.fo.re'gu.la. L. pref. de from; L. n. sulfur sulfur; L. n. fem regula a straight piece of wood or ruler; N.L. fem. n. Desulforegula a sulfatereducing bacterium shaped like a ruler).

Cells are Gram-negative, straight rods and can be motile. Strict anaerobes that use sulfate as a terminal electron acceptor. Desulforegula belongs to the $\delta$ subclass of the Proteobacteria. The nearest relatives are Desulfofaba, Desulfobacterium and Desulfonema. The type species is Desulforegula conservatrix.

\section{Description of Desulforegula conservatrix sp. nov.}

Desulforegula conservatrix (con.ser.va'trix. L. fem. n. conservatrix she who preserves, describing the storage of lipid cell inclusions).

Cells are rod-shaped, $1-1 \cdot 3 \mu \mathrm{m}$ wide and $2 \cdot 6-3 \mu \mathrm{m}$ long. The maximum temperature for growth is $32^{\circ} \mathrm{C}$, with optimum growth occurring between 25 and $30^{\circ} \mathrm{C}$. Optimum growth occurs with up to $1.0 \mathrm{~g} \mathrm{NaCl} 1^{-1}$. Slow growth occurs in medium with $5 \mathrm{~g} \mathrm{NaCl}^{-1}$. Oxidizes straight-chain carboxylic acids with 4-17 carbon atoms. No other substrates are known to be utilized. Substrates are incompletely oxidized. No growth occurs in the absence of sulfate. Habitat: sediment of freshwater lake. The type strain is $\mathrm{Mb} \mathrm{Pa}^{\mathrm{T}}$ $\left(=\right.$ DSM $13527^{\mathrm{T}}=$ ATCC BAA- $\left.134^{\mathrm{T}}\right)$.

\section{ACKNOWLEDGEMENTS}

This work was supported by the University of Canberra (grant 98/474) and the Cooperative Research Centre for Freshwater Ecology (Project B400). We thank Professor H. G. Trüper for assistance with the naming of the organism.

\section{REFERENCES}

Aeckersberg, F., Bak, F. \& Widdel, F. (1991). Anaerobic oxidation of saturated hydrocarbons to $\mathrm{CO}_{2}$ by a new type of sulfatereducing bacterium. Arch Microbiol 156, 5-14.

Altschul, S. F., Gish, W., Miller, W., Myers, E. W. \& Lipman, D. J. (1997). Basic local alignment search tool. J Mol Biol 215, 403-410.

Andrews, K. T. \& Patel, B. K. C. (1996). Fervidobacterium gondwanense sp. nov., a new thermophilic anaerobic bacterium isolated from nonvolcanically heated geothermal waters of the Great Artesian Basin of Australia. Int J Syst Bacteriol 46, 265-269.

Ausubel, F. M., Brent, R., Kingston, R. E., Moore, D. D., Seidmen, J. G., Smith, J. A. \& Struhl, K. (1997). Short Protocols in Molecular Biology, 3rd edn. New York: Wiley.

Bak, F. \& Widdel, F. (1986). Anaerobic degradation of indolic compounds by sulfate-reducing enrichment cultures, and description of Desulfobacterium indolicum gen. nov., sp. nov. Arch Microbiol 146, 170-176.

Benson, D. A., Karsch-Mizrachi, I., Lipman, D. J., Ostell, J., Rapp, B. A. \& Wheeler, D. L. (2000). GenBank. Nucleic Acids Res 28, 15-18.

Drzyzga, O., Küver, J. \& Blotevogel, K. H. (1993). Complete oxidation of benzoate and 4-hydroxybenzoate by a new sulfate- reducing bacterium resembling Desulfoarculus. Arch Microbiol 159, 109-113.

Felsenstein, J. (1993). PHYLIP (Phylogenetic Inference Package) version 3.51c. Distributed by the author. Department of Genetics, University of Washington, Seattle, USA.

Janssen, P. H. \& O'Farrell, K. A. (1999). Succinispira mobilis gen. nov., sp. nov., a succinate-decarboxylating anaerobic bacterium. Int J Syst Bacteriol 49, 1009-1013.

Janssen, P. H., Schuhmann, A., Mörschel, E. \& Rainey, F. A. (1997). Novel anaerobic ultramicrobacteria belonging to the Verrucomicrobiales lineage of bacterial descent isolated by dilution culture from anoxic rice paddy soil. Appl Environ Microbiol 63, 1382-1388.

Jukes, T. H. \& Cantor, C. R. (1969). Evolution of protein molecules. In Mammalian Protein Metabolism, pp. 21-132. Edited by H. N. Munro. New York: Academic Press.

Knoblauch, C., Sahm, K. \& Jørgensen, B. B. (1999). Psychrophilic sulfate-reducing bacteria isolated from permanently cold Arctic marine sediments: description of Desulfofrigus oceanense gen. nov., sp. nov., Desulfofrigus fragile sp. nov., Desulfofaba gelida gen. nov., sp. nov., Desulfotalea psychrophila gen. nov., sp. nov., and Desulfotalea arctica sp. nov. Int J Syst Bacteriol 49, 1631-1643.

Maidak, B. L., Cole, J. R., Lilburn, T. G. \& 9 other authors (2000). The RDP (Ribosomal Database Project) continues. Nucleic Acids Res 28, 173-174.

Marmur, M. (1961). A procedure for the isolation of deoxyribonucleic acid from microorganisms. J Mol Biol 3, 201-218.

Ostle, A. G. \& Holt, J. G. (1982). Nile blue A as a fluorescent stain for poly- $\beta$-hydroxybutyrate. Appl Environ Microbiol 44, 238-241.

Pitcher, D. G., Saunders, N. A. \& Owen, R. J. (1989). Rapid extraction of bacterial genomic DNA with guanidium isothiocyanate. Lett Appl Microbiol 8, 151-156.

Postgate, J. R. (1959). A diagnostic reaction of Desulphovibrio desulphuricans. Nature 183, 481-482.

Rabus, R., Nordhaus, R., Ludwig, W. \& Widdel, F. (1993). Complete oxidation of toluene under strictly anoxic conditions by a new sulfate-reducing bacterium. Appl Environ Microbiol 59, 1444-1451.

Redburn, A. C. \& Patel, B. K. C. (1993). Phylogenetic analysis of Desulfotomaculum thermobenzoicum using polymerase chain reaction-amplified 16S rRNA-specific DNA. FEMS Microbiol Lett 113, 81-86.

Rees, G. N., Rainey, F. A. \& Harfoot, C. G. (1994). Characterization of a novel obligate anaerobe that ferments agar. Arch Microbiol 162, 395-400.

Rees, G. N., Grassia, G. S., Sheehy, A. J., Dwivedi, P. P. \& Patel, B. K. C. (1995). Desulfacinum infernum gen. nov., sp. nov., a thermophilic sulfate-reducing bacterium from a petroleum reservoir. Int J Syst Bacteriol 45, 85-89.

Rees, G. N., Patel, B. K. C., Grassia, G. S. \& Sheehy, A. J. (1997). Anaerobaculum thermoterrenum gen. nov., sp. nov., a novel, thermophilic bacterium which ferments citrate. Int $J$ Syst Bacteriol 47, 150-154.

Rees, G. N., Harfoot, C. G. \& Sheehy, A. J. (1998). Amino acid degradation by the mesophilic sulfate-reducing bacterium Desulfobacterium vacuolatum. Arch Microbiol 169, 76-80.

Reuter, P., Rabus, R., Wilkes, H., Aeckersberg, F., Rainey, F. A., Jannasch, H. W. \& Widdel, F. (1994). Anaerobic oxidation of hydrocarbons in crude oil by new types of sulphate-reducing bacteria. Nature 372, 455-458. 
Schnell, S. \& Schink, B. (1992). Anaerobic degradation of 3aminobenzoate by a newly isolated sulfate reducer and a methanogenic enrichment culture. Arch Microbiol 158, 328-334.

Widdel, F. (1980). Anaerober Abbau von Fettsäuren und benzoesäure durch neu isolierte Arten Sulfat-reduzierender Bakterien. PhD thesis, Göttingen University.

Widdel, F. (1988). Microbiology and ecology of sulfate- and sulfur-reducing bacteria. In Biology of Anaerobic Microorganisms, pp. 469-585. Edited by A. J. B. Zehnder. New York: Wiley.

Widdel, F. \& Bak, F. (1992). Gram negative mesophilic sulfatereducing bacteria. In The Prokaryotes: a Handbook on the Biology of Bacteria-Ecophysiology, Isolation, Identification, Applications, 2nd edn, pp. 3352-3378. Edited by A. Balows, H. G. Trüper, M. Dworkin, W. Harder \& K.-H. Schleifer. Berlin, Heidelberg \& New York: Springer.
Widdel, F., Kohring, G. W. \& Mayer, F. (1983). Studies on dissimilatory sulfate-reducing bacteria that decompose fatty acids. III. Characterization of the filamentous gliding Desulfonema limicola gen. nov. sp. nov., and Desulfonema magnum sp. nov. Arch Microbiol 134, 286-294.

Wind, T., Stubner, S. \& Conrad, R. (1999). Sulfate-reducing bacteria in rice field soil and on rice roots. Syst Appl Microbiol 22, 269-279.

Winker, S. \& Woese, C. R. (1991). A definition of the domains Archaea, Bacteria and Eucarya in terms of small subunit ribosomal RNA characteristics. Syst Appl Microbiol 13, 161-165.

Woo, T. H. S., Patel, B. K. C., Smythe, L. D., Symonds, M. L., Norris, M. A. \& Dohnt, M. F. (1997). Identification of pathogenic Leptospira by TaqMan Probe in a LightCycler ${ }^{\mathrm{TM}}$. Anal Biochem 256, 132-134. 